\section{Perbandingan Return On Asset, Return On Equity, Gross Profit Margin, Operating Profit Margin, dan Net Profit Margin Sebelum dan Semasa Covid-19 Pada PT. Matahari Departement Store, Tbk}

Company Financial

Ratios and

Covid-19 Pandemic

61

Jefriyanto

Program Studi Akuntansi, Sekolah Tinggi Ilmu Ekonomi Mahaputra Riau

EMail: jefriinfo@gmail.com

\begin{abstract}
This study aims to determine the impact of covid-19 on profitability at PT. Matahari Department Store, Tbk. Profitability is the ratio used to measure the level of profit obtained from sales and investment. Profitability concerns are Return on Assets (ROA), Return on Equity (ROE), Gross Profit Margin (GPM), Operating Profit Margin (OPM) and Net Profit Margin (NPM). The data is secondary data which includes financial reports for 2019 and 2020. The analysis tools is the profitability ratio and for analyzing the data, this study uses a descriptive method. The results of this study indicate that ROA, ROE, GPM, OPM and NPM have decreased between 2019 and 2020. This is because companies no longer have any profits in 2020. This decrease is due to the covid-19 outbreak which has caused national and international economies issues, including PT. Matahari Department Store, Tbk.
\end{abstract}

Keywords: Profitability, ROA, ROE, GPM, OPM, NPM

\section{ABSTRAK}

Penelitian ini bertujuan untuk mengetahui dampak adanya covid-19 terhadap profitabilitas pada PT. Matahari Departemen Store, Tbk. Profitabilitas merupakan rasio yang digunakan untuk mengukur tingkat keuntungan yang didapat dari penjualan dan investasi. Profitabilitas menyangkut Return on Asset (ROA), Return on Equity (ROE), Gross Profit Margin (GPM), Operating Profit Margin (OPM) dan Net Profit Margin (NPM). Data yang digunakan adalah data sekunder yang meliputi laporan keuangan tahun 2019 dan 2020. Alat analisis yang digunakan adalah rasio profitabilitas dan dalam menganalisa data penulis menggunakan metode deskriptif. Hasil penelitian ini menunjukan bahwa ROA, ROE, GPM, OPM dan NPM mengalami penurunan antara tahun 2019 dan 2020. Hai ini dikarenakan perusahaan sudah tidak lagi membukukan laba pada tahun 2020. Penurunan ini akibat terjadinya wabah covid-19 yang membuat ekomoni nasional dan internasional mengalami penurunan, termasuk PT. Matahari Departement Store, Tbk.

Kata Kunci: Profitabilitas, ROA, ROE, GPM, OPM, NPM

\section{PENDAHULUAN}

Pernyataan standar akuntansi (PSAK) No.01 menjelaskan bahwa tujuan laporan keuangan adalah menyediakan informasi yang menyangkut posisi keuangan, kinerja, serta perubahan posisi keuangan suatu perusahaan yang bermanfaat pagi sejumlah besar pemakai dalam pengambilan keputusan. Agar laporan keuangan menjadi lebih bermakna, laporan keuangan tersebut harus dapat dipahami dan dimengerti oleh penggunanya sehingga perlu dilakukan analsisis terhadap laporan keuangan. Analisis laporan keuangan merupakan merupakan suatu prose untuk membedah laporan keuangan ke dalam unsur-unsurnya dan menelaah masing-masing dari unsur tersebut

\section{JIAKES}

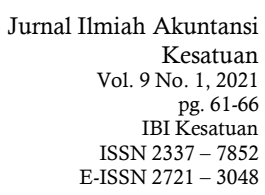


Company Financial dengan tujuan untuk memperoleh pengertian dan pemahaman yang baik dan tepa tatas

Ratios and

Covid-19 Pandemic laporan keuangan itu sendiri (hery, 2016). Analisis rasio keuangan bagian analisis prestasi yang di dalamnya terdapat penjelasan keterkaitan antar laporan keuangan dengan tujuan menunjukan perubahan dalam kondisi keuangan atau prestasi operasi di masa lalu dan membantu menggambarkan trend pola perubahan tersebut, untuk kemudian menunjukan rasio dan peluang yang melekat pada perusahaan yang bersangkutan. (fahmi, 2015)

Kebijakan perusahaan yang menyangkut dengan keuangan, keputusan yang diambil pihak pemangku kepentingan sebaiknya diputuskan berdasarkan rasio keuangan. Hal tersebut dimaksudkan agar setiap keputusan yang dibuat dalam hal keuangan, tidak salah dalam hal memberikan informasi yang berguna kepada pihak-pihak terkait. Sangat Penting untuk berhati-hati dalam memutuskan kebijakan manajemen perusahaan, karena berhubungan dengan berbagai kepentingan perusahaan. Kesalahan menentukan keputusan, akan berakibat pada kerugian. Pertimbangan keputusan yang dikeluarkan dengan berdasar pada rasio keuangan merupakan langkah yang bijak. Pasalnya, manajemen bisa memprediksi perkembangan perusahaan di masa yang akan datang. Dengan demikian, lebih tahu langkah apa saja yang harus dilakukan agar perusahaan dapat bertahan. Wajar, bila sering menemui perusahaan yang yang melakukan PHK para karyawannya. Hal tersebut dilakukan agar perusahaan dapat bertahan selama beberapa tahun ke depan. Disamping itu, rasio keuangan digunakan untuk menyelamatkan aset perusahaan, serta meminimalisir resiko kebangkrutan.

Tingkat profitabilitas akan menggambarkan posisi laba perusahaan. Para investor di pasar modal sangat memperhatikan kemampuan perusahaan dalam menghasilkan dan meningkatkan laba, hal ini merupakan daya tarik bagi investor dalam melakukan jual beli saham, oleh karena itu manajemen harus mampu memenuhi target yang telah ditetapkan. Maka untuk mengukur tingkat keuntungan suatu perusahaan, digunakanlah rasio profitabilitas yang dikenal juga dengan rasio rentabilitas. (Kasmir, 2012) mengatakan, rasio profitabilitas memberikan ukuran tingkat efektivitas manajemen suatu perusahaan, karena menunjukkan laba yang dihasilkan dari penjualan dan pendapatan investasi. Penggunaan rasio profitabilitas dapat dilakukan dengan menggunakan perbandingan antara berbagai komponen yang ada di laporan laba rugi. Pengukuran dapat dilakukan untuk beberapa periode operasi agar terlihat perkembangan perusahaan dalam rentang waktu tertentu. Setelah mengetahui hasil perkembangan maka akan dijadikan alat evaluasi kinerja manajemen selama ini. Bila sudah berjalan dengan baik maka harus dipertahankan untuk menjadi lebih baik tetapi bila tidak berjalan dengan baik maka pihak manajemen harus berusaha memperbaikinya. Oleh karena itu, rasio ini disebut sebagai salah satu alat ukur kinerja manajemen.

Maulan irwadi (2017) melakukan penelitian tentang analisis rasio unutk menilai kinerja keuangan pada PT Sarwa Karya Wiguna Palembang dengan hasil bahwa GPM terus mengalami peningkatan, kinerja perusahaan sudah baik karena berada diatas standar rasio industri perusahaan sejenis. Perusahaan sudah baik dalam mengendalikan biaya penjualan serta meningkatkan penjualan. Namun untun NPM dan ROI menunjukan bahwa kinerja perusaahn tidak sehat. Perusahaan tidak dapat menekan biaya-biaya yang tidak perlu sehingga perusahaan tidak mampu memaksimalkan laba bersih yang diperoleh. Perusahaan terlalu banyak melakukan investasi diluar perusahaan.

Tahun 2020 merupakan tahun terberat bagi kebanyakan perusahaan dalam menjalankan usahanya dikarenakan wabah covid-19 yang melanda hampir seluruh penjuru dunia. Banyak pengusaha yang memutuskan memberhentikan karyawan atau bahkan tidak sedikit yang memutuskan menyudahi usahanya. Hal ini dikarenakan kemampuan perusahaan dalam hal pembiayaan semua sektor baik internal maupun eksternal dalam keadaan yang kurang memungkinkan. Di kala pemerintah sedang berupaya untuk mengoptimalkan kondisi perekonomian Indonesia, pandemic Covid19 datang dengan segala dampak negatifnya. Seperti yang kita ketahui sekarang bahwa dampak dari pandemi ini sangat berpengaruh dalam segala aspek terutama pada kondisi kesehatan dan perekonomian Negara. Dengan adanya pandemi Covid-19 tidak dapat dipungkiri bahwa perekonomian Indonesia saat ini sedang berada dalam kondisi yang 
bisa dibilang "sangat tidak stabil". berdasarkan pertumbuhan dari tahun ke tahun, sumber pertumbuhan ekonomi Indonesia pada triwulan 12020 terbesar pada sektor informasi dan komunikasi sebesar 0,53 persen. Hal ini cukup bisa dimaklumi mengingat dengan adanya anjuran dari pemerintah untuk "di rumah saja" maka banyak orang menjalankan pekerjaan, hiburan dan pendidikan melalui teknologi informasi. Seiring hal tersebut, volume penjualan listrik PLN ke rumah tangga pun otomatis meningkat. Berdasarkan rilis dari Badan Pusat Statistik, jumlah wisatawan mancanegara yang datang ke Indonesia pada Triwulan 12020 juga turun drastis hanya sejumlah 2,61 juta kunjungan, berkurang 34,9 persen bila dibandingkan dengan tahun lalu. Hal ini sejalan dengan adanya larangan penerbangan antar negara yang mulai diberlakukan pada pertengahan Februari lalu. Jumlah penumpang angkutan rel dan udara juga tumbuh negative seiring dengan diberlakukannya PSBB. (kompas.com, 2020)

Kajian penelitian ini menyangkut Return On Asset, Return On Equity, Gross Profit Margin, Operating Profit Margin, dan Net Profit Margin dengan membandingkan tahun 2019 dan 2020 untuk dapat melihat ada atau tidaknya perbedaan profitabilitas yang signifikan pada perusahaan yang menjadi objek penelitian ini. Yaitu PT. Matahari Departemen Store, Tbk.

Profitabilitas merupakan alat analisis yang digunakan untuk mengukur kemampuan perusahaan dalam menghasilkan laba dari aktivitas normal bisnisnya (hery, 2016). Disamping untuk mengtahui kemampuan perusahaan dalam menghasilkan laba selama periode tertentu, profitablitas juga bertujuan untuk mengukur tingkat efektifitas manajemen dalam menjalankan operasioanal perusahaan. Profitabilitas juga merupakan rasio yang menggambarkan kemampuan perusahaan dalam menghasilkan laba melalui semua kemampuan dan sumberdaya yang dimilikinya, yaitu yang berasal dari kegiatan penjualan, penggunaan asset, maupun penggunaan modal. Kinerja yang baik akan ditunjukan lewat keberhasilan menajemen dalam menghasilkan laba yang maksimal bagi perusahaan. Pengukuran profitabilitas dapat dilakukan dengan membandingkan antara berbagai komponen yang ada dalam laporan laba rugi dan neraca. Pengukuran dapat dilakukan untuk beberapa periode dengan tujuan memonitor dan mengevaluasi tingkat perkembangan profitabilitas perusahaan dari waktu ke waktu.

Return On Asset (ROA) mengukur kemampuan perusahaan menghasilkan laba bersih berdasarkan tingkat aset tertentu" (Han afi, 2008:42). Semakin tinggi Return on Asset suatu perusahaan, semakin besar pula tingkat keuntungan yang dicapai oleh perusahaan. Return on Asset perlu dipertimbangkan oleh investor dalam berinvestasi saham, karena Return on Asset berperan sebagai indikator efisiensi perusahaan dalam menggunakan aset untuk memperoleh laba: $\boldsymbol{R O A}=$ Laba Bersih $:$ Total Aset

Return on Equity mengukur kemampuan perusahaan menghasilkan laba bersih berdasarkan modal tertentu"(Hanafi, 2008). Kenaikan rasio ini berarti terjadi kenaikan laba bersih dari perusahaan yang bersangkutan. Jadi, para investor dapat menggunakan indikator ROE sebagai bahan pertimbangan dalam memilih saham atau menanamkan modalnya, karena rasio ini menunjukkan bahwa dengan kinerja manajemen meningkat maka perusahaan dapat mengelola sumber dana pembiayaan operasional secara efektif untuk menghasilkan laba bersih sehingga saham perusahaan banyak diminati investor.

\section{ROE = Laba Bersih : Total Modal}

Gross Profit Margin (GPM) merupakan rasio yang digunakan untuk mengukur besarnya persentase laba kotor atas penjualan. (hery, 2016). Semakin tinggi GPM berarti semakin tinggi pula laba kotor yang dihasilkan oleh penjualan bersih. GPM merupakan presentase laba kotor dibandingkan dengan sales. Semakin besar gross profit margin semakin baik keadaan operasi perusahaan. Karna hal ini menunjukkan bahwa harga pokok penjualan relatif lebih rendah dibandingkan dengan sales, demikian pula sebaliknya, semakin rendah Gross Profit Margin semakin kurang baik operasi perusahaan (Syamsudin, 2009). GPM = Laba Kotor : Penjualan Bersih

Operating Profit Margin (OPM). Rasio ini menggambarkan beban-beban operasional perusahaan serta harga pokok penjualannya. Menurut Syamsudin (2009) semakin tingi
Financial Ratios and COVID-19

Pamdemic 
Company Financial Operating Profit Margin akan lebih baik pula operasi perusahaan. Operating Profit

Ratios and

Covid-19 Pandemic
Margin merupakan perbandingan antara laba usaha dan penjualan. Operating Profit Margin merupakan rasio yang menggambarkan apa yang biasanya disebut pure profit yang diterima atas setiap rupiah dari penjualan yang dilakukan (Syamsudin, 2009). OPM = Laba Operasional : Penjualan Bersih

Net Profit Margin merupakan rasio yang digunakan untuk mengukur besarnya persentase laba bersih atas penjualan bersih (hary, 2016). Rasio ini dihitung dengan membagi laba bersih terhadap penjualan bersih. laba bersih sendiri dihitung sebagai hasil pengurangan antara laba sebelum pajak penghasilan dengan beban pajak penghasilan. Yang dimaksud dengan laba sebelum pajak penghasilan disini adalah laba operasional ditambah pendapatan dan keuntungan lain-lain, lalu dikurangi dengan beban dan kerugian lain-lain. $N P M=$ Laba Bersih $:$ Penjualan Bersih

\section{METODOLOGI PENELITIAN}

Metode analisis data yang digunakan adalah menggunakan metode kualitatif. Proses tersebut meliputi pengelolaan data, penjabaran hasil penelitian secara deskriptif serta diakhiri dengan penarikan kesimpulan yang bersifat kualitatif dengan membandingkan antara fakta-fakta yang terjadi. Objek pada penelitian ini adalah PT. Matahari Departemen Store, Tbk. Data yang digunakan dalam penelitian ini adalah data sekunder. Sugiyono (2012) mengatakan Data primer merupakan sumber data yang langsung memberikan data kepada pengumpul data. atau data yang diperoleh secara langsung dari perusahaan berupa data mentah yang perlu diolah lagi, Dan data sekunder merupakan sumber data yang tidak langsung memberikan data kepada pengumpul data, misalnya lewat orang lain atau dokumen. Dalam mengumpulkan data, dilakukan dengan cara studi pustaka dengan literatur yang berhubungan dengan topik penelitian

Dalam menganalisa data penulis menggunakan metode deskriptif, menurut Sugiyono (2001) metode deskriptif yaitu dengan mengumpulkan, mengelolah, dan menginterpretasikan data yang diperoleh sehingga dapat memberikan gambaran yang jelas mengenai keadaan yang diteliti. Dalam melakukan penelitian ini analisis terhadap laporan keuangan perusahaan, penulis menggunakan alat analisis Rasio Profitabilitas.

HASIL DAN PEMBAHASAN

Tabel 1. Profitabilitas PT Matahari Departemen Store,Tbk. 2019-2020

\begin{tabular}{|c|c|c|c|}
\hline \multirow{2}{*}{ No } & \multirow{2}{*}{ Keterangan } & \multicolumn{2}{|c|}{ Tahun } \\
\cline { 3 - 4 } & & $\mathbf{2 0 2 0}$ & $\mathbf{2 0 1 9}$ \\
\hline 1 & ROA & $(0,14)$ & 0,28 \\
\hline 2 & ROE & $(1,5)$ & 0,78 \\
\hline 3 & GPM & 0,71 & 0,76 \\
\hline 4 & OPM & $(0,15)$ & 0,22 \\
\hline 5 & NPM & $(0.22)$ & 0,17 \\
\hline
\end{tabular}

ROA digunakan sebagai pengukur seberapa besar jumlah laba bersih yang akan dihasilkan dari setiap rupiah dana yang tertanam dalam total asset. Dari hasil perhitungan ROA dalam table, dapat dilihat jelas bahwa ROA 2019 Jauh lebih baik jika dibandingkan dengan ROA 2020. Hal ini dikarenakan pada tahun 2020 perusahaan tidak mengalami laba. PT Matahari Departemen Store mengalami kerugian -873.181 (dalam jutaan). Jadi, asset 2020 tidak memiliki kontribusi untuk menghasilkan laba bersih. Berbeda hal dengan tahun 2019, dimana asset memiliki kontribusi menciptakan 0,28 laba bersih. ROE digunakan untuk mengukur seberapa besar jumlah laba bersih yang akan dihasilkan dari setiap rupiah dana yang tertanam dalam total modal. Sama hal nya dengan ROA, untuk tahun 2020 Modal tidak memiliki kontribusi dalam menghasilkan laba bersih perusahaan. Sedangkan pada tahun 2019 Modal masih berkontribusi 0,78 dalam hal 
menghasilkan laba bersih perusahaan. GPM digunakan untuk mengukur besarnya persentase laba kotor atas penjualan bersih. GPM tahun 2019 lebih baik dari 2020 yaitu 0,76 dan 0,71 . Namun pada tahun 2020 perusahaan masih mampu mengantongi laba kotor 0,71 dari total penjualan bersihnya. OPM digunakan untuk mengukur besarnya persentase laba operasi terhadap penjualan bersih. Besarnya laba operasional untuk tahun 2019 adalah 0,22 , artinya besarnya laba operasional adalah 0,22 dari total penjualan bersih. hal ini tidak terjadi lagi di tahun 2020 dimana perusahaan mengalami minus pada laba operasi (-626.706). NPM digunakan untuk mengukur besarnya persentase laba bersih atas penjualan bersih. NPM tahun 2019 adalah 0,17, artinya penjualan bersih masih mampu menghasilkan laba bersih sebesar 0,17. Berbeda dengan tahun 2020 dimana seperti diketahui bahwa perusahaan mengalami kerugian. Penjualan bersih tidak mampu menciptakan laba bersih perusahaan.

Covid-19 mulai masuk ke Indonesia pada awal tahun 2020. Menteri Keuangan Republik Indonesia mengatakan bahwa proyeksi pertumbuhan ekonomi Indonesia hanya akan mencapai 2,3\%. Bahkan jika dalam situasi terburuk, ekonomi Indonesia bisa minus hingga $0,4 \%$. Penyebab dari rendahnya pertumbuhan ekonomi Indonesia ini adalah turunnya minat konsumsi dan investasi masyarakat, baik dalam lingkup rumah tangga maupun lingkup pemerintah.dari sektor industri banyak para pengusaha yang bahkan memberhentikan proses produksi diikuti dengan pemutusan hubungan kerja dengan para karyawannya. Dari hasil penelitian ini diketahui bahwa hasil penjualan sebelum dan semasa covid-19 terjadi, yaitu 10,276,431 untuk tahun 2019 dan 4,839,058 untuk tahun 2019 , dimana penurunan penjualan ini hamper mencapai angka 50\%. PT. Matahari departemen Store tahun 2019 masih membukukan laba sebesar 1,366,884. Sedangkan tahun 2020 kerugian yang dibukukan mencapai angka 873,181.

\section{PENUTUP}

Analisis profitabilitas yang dilakukan menyangkut ROA, ROE, GPM, OPM, dan NPM di temukan hasil bahwa ROA 2019 Jauh lebih baik jika dibandingkan dengan ROA 2020. Hal ini dikarenakan pada tahun 2020 perusahaan mengalami kerugian. Berbeda hal dengan tahun 2019, dimana asset memiliki kontribusi menciptakan 0,28 laba bersih. ROE Sama hal nya dengan ROA, untuk tahun 2020 Modal tidak memiliki kontribusi dalam menghasilkan laba bersih perusahaan. Sedangkan pada tahun 2019 Modal masih berkontribusi 0,78 dalam hal menghasilkan laba bersih perusahaan. GPM tahun 2019 lebih baik dari 2020 yaitu 0,76 dan 0,71 . Namun pada tahun 2020 perusahaan masih mampu mengantongi laba kotor 0,71 dari total penjualan bersihnya. OPM digunakan untuk mengukur besarnya persentase laba operasi terhadap penjualan bersih. Besarnya laba operasional untuk tahun 2019 adalah 0,22 , artinya besarnya laba operasional adalah 0,22 dari total penjualan bersih. hal ini tidak terjadi lagi di tahun 2020 dimana perusahaan mengalami minus pada laba operasi (-626.706). NPM digunakan untuk mengukur besarnya persentase laba bersih atas penjualan bersih. NPM tahun 2019 adalah 0,17, artinya penjualan bersih masih mampu menghasilkan laba bersih sebesar 0,17 . Berbeda dengan tahun 2020 dimana seperti diketahui bahwa perusahaan mengalami kerugian. Penjualan bersih tidak mampu menciptakan laba bersih perusahaan.

\section{DAFTAR PUSTAKA}

Andres, Hendry Maith. (2013). Analisis Laporan Keuangan Dalam Mengukur Kinerja Keuangan Pada PT. Hanjaya Mandala Sampoerna Tbk. Manado: Jurnal Universitas Sam Ratulangi

Fahmi, Irham. (2015). Pengantar Manajemen Keuangan Teori dan Soal Jawab. Bandung: Penerbit Alfabeta

Hery, (2016). Analisis Laporan Keuangan Integrated and Comprehensive Edition. Jakarta: Grasindo.

\author{
Company \\ Financial Ratios \\ and COVID-19 \\ Pamdemic
}


Company Financial Irwadi, M. (2017). Analisis Rasio Keuangan Untuk Menilai Kinerja Keuangan pada PT. Sarwa Ratios and KaryaWiguna Palembang. Jurnal Akuntanika, Vol 3 No. 2.

Covid-19 Pandemic Kasmir. (2015). Analisis Laporan Keuangan. Jakarta : PT. Raja Grafindo Persada Syafri Harahap, Sofyan. 2008. Analisa Kristis atas Laporan Keuangan. Jakarta: PT. Raja Grafindo Persada.

Nugroho, Muhammad Aji. 2010. Analisis Perbandingan Kinerja Keuangan Perusahaan Sebelum dan Sesudah Merger dan Akuisisi (Pada Perusahaan Pengakuisisi, periode 2002- 2003). Disertasi. Universitas Diponegoro.

Rubianti, Nana. (2013). Analisa Rasio Keuangan Untuk Menilai Kinerja Perusahaan Pada PT. Admiral Lines Cabang TanjungPinang. Tanjung Pinang: Jurnal Universitas Maritim Raja Ali Haji

Sembiring, H. (2012). Analisis Pengaruh Karakteristik Perusahaan Terhadap Kelengkapan Pengungkapan dalam Laporan Tahunan Perusahaan Manufaktur yang Terdaftar di Bursa Efek Indonesia. Jurnal Mediasi, 4(1), 68-77. 